\title{
Needs Analysis on Developing EFL Paragraph Writing Materials at Kalimantan L2 learners
}

\author{
Sabarun $^{1}$ \\ ${ }^{1}$ English Department of IAIN Palangka Raya, Jalan G. Obos 22 Kompleks Islamic Centre Palangka Raya, \\ Indonesia \\ Correspondence: Sabarun, English Department of IAIN Palangka Raya, Jalan G. Obos 22 Kompleks Islamic \\ Centre Palangka Raya, Indonesia
}

Received: November 13, 2018

Accepted: December 21, 2018 Online Published: December 24, 2018

doi: $10.5539 /$ elt.v12n1p186

URL: https://doi.org/10.5539/elt.v12n1p186

\begin{abstract}
This study attempts to explore the target needs and the learning needs. This research was conducted at the second semester English department students of Palangka Raya State Islamic Institute of 2017/ 2018 academic years. The respondent was $20 \mathrm{EFL}$ paragraph writing learners. The research findings were as follows: (a) in terms of the target language needs, it revealed that majority of learners (45\%) were studying Paragraph Writing course; (b) it was found that majority of the respondents $(50 \%)$ stated that the skills to develop through the paragraph writing course was the understanding the paragraph development; (c) it was found that majority of respondents said that grammar (45\%) and mind mapping (40\%) was the students' difficulty in writing paragraph; (d) in terms of learning style, the learners preferred to get assistance from Internet than other sources, and they preferred to self-learning in the classroom activities. In terms of the learners' appropriate teaching methods it was found that (a) Internet was preferred dominantly by the respondents $(75 \%)$ as source to be included as instructional materials; (b) the source of corrective feedback preferred mostly by the respondents $(80 \%)$ was teacher feedback. Therefore, it is recommended that internet-based materials are preferred for developing EFL writing materials. The materials should be made excellent integration of resources available on the web.
\end{abstract}

Keywords: needs analysis, developing, writing materials

\section{Introduction}

Needs analysis (NA) is considered as a vital thing in making the design on language course. Needs analysis is a way for collecting data about learners' needs. Needs Analysis raised in the 1960s. In the view of Iwai et al. (1999), needs analysis is the procedure involving in gathering data to be the foundation for designing syllabus and curriculum suitable with the learners' needs. The deep investigation of the needs analysis is related to the development of curriculum (e.g. Bosher \& Smalkowski, 2012; Chaudron et al., 2005). Yalden (2012) concerned to NA attempting to relate a relation between learners' wants and their needs. Regarding this element, Kaewpet (2009) argued that the learners' needs depend on many hopes, prediction and personal judgments. He emphasised that some researchers on needs analysis should have attitudes concerning language needs. This is accordance with Songhori (2007). He states that the idea of needs analysis includes environment situation; personal information on students - some factors affecting the learning method; learners' language information about their current skills and language use; learners' weakness/ lacks; learners' needs from course; and language learning needs. Furthermore, NA has been considered as an urgent thing in the curriculum development. The insertion of NA in EFL curriculum began in 1960 as language programs started focusing English for Specific Purposes (ESP) instruction (Hamp-Lyons, 2001; Finney, 2002). Formerly, needs analysis was firstly developed in language teaching through the ESP context during 1960s to 1970s. However, this needs analysis was not only for ESP, but also for EFL learners in general. The present study focuses on conducting NA on developing EFL paragraph writing materials in the context of Kalimantan EFL learners.

In my opinion, needs analysis is a way of finding out the types of writing tasks learners need to be able to do, and the knowledge and skills they need to acquire so as to carry out those tasks. It is, therefore, a continual process where course designers ask questions and propose solutions, and even consult the learners themselves, to determine the gap between what learners are taught to do in academic writing courses and what is required of them across the curriculum in their content courses. This study attempts to explore the target English language 
needs of the students in Paragraph Writing class at English Department Students of IAIN Palangka Raya, in terms of (a) necessities; (b) wants; and (c) lacks; and to explain the learning needs of the students, in terms of (a) preferred style of learning; (b) the appropriate teaching methods. The students' learning needs for the English writing skill as the basis for designing the learning materials. Need survey is carried out to describe the students' needs, wants, and lacks for paragraph writing materials of English Education Study Program at IAIN Palangka Raya.

\section{Methods}

The design of this research is descriptive study. In the current research, the respondents of the research is the 2B class students of the second semester English department of Palangka Raya State Islamic College of 2017/ 2018 academic years. The number of respondents is $20 \mathrm{EFL}$ learners. There are two instruments developed in conducting the study, namely, observation and questionnaire to collect the data. The questionnaire is the main source of data collection. It consisted of fifteen multiple choice questions and one explanatory question. Meanwhile, explanatory question will allow the researcher to receive explanatory answers (Brown, 2001, p. 36). The questionnaire is distributed to gain the data about their wants, needs, and lacks the students who are taking Paragraph Writing course. The questionnaire for the study is divided into four parts: Part 1 covered the target needs of the students in Paragraph Writing class in terms of their necessities. It consisted of two questions. Part 2 dealt with the target needs of the students in Paragraph Writing class in terms of their wants. It consisted of one question with four options. Part 3 dealt with the target needs of the students in Paragraph Writing class in terms of their lacks. It consisted of two questions. Part 4 covered the learning needs of the students. This included the learners preferred style of learning (two questions), and learners' appropriate teaching methods in L2 writing class. It consisted of 5 questions, one learner's suggestion. In the questionnaire, the respondents are asked to choose their responses by giving a circle on a letter representing their choice. Four different choices will be offered to them; A, B, C, or D. It is used to describe the respondents' choice about the questions given. The respondents' choice is about the target English language needs of the students in Paragraph Writing class in terms of (a) necessities; (b) wants; and (c)lacks; and the learning needs of the students, in terms of (a) preferred model/ style of learning chosen by learners; (b) the suitable teaching procedures.

\section{Results}

The study attempts to investigate the target needs and the learning needs of the students in Paragraph Writing class, in terms of (a) necessities; (b) wants; and (c) lacks; and the learning needs of the students, in terms of (a) preferred style of learning chosen by learners; (b) the suitable teaching procedures. The findings concluded:

1) Dealing with learning targets in terms of necessity it was clear some learners (45\%) were studying Paragraph Writing course because they wanted to be more literate in writing. $30 \%$ of learners believed that learning EFL Paragraph Writing was important to look for good job, as illustrated in Figure 1.

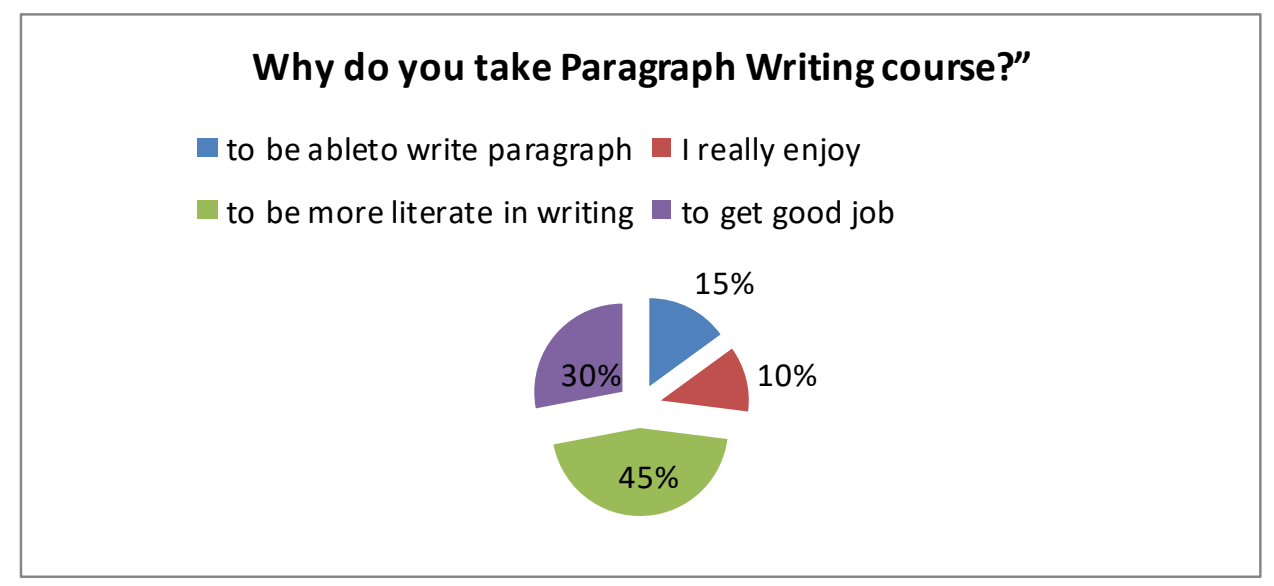

Figure 1. The reasons to choose paragraph writing course

The participants gave different response. 3 out of twenty participants or $15 \%$ said that they were going to be able to write a good paragraph. 2 of them (10\%) responded that paragraph writing class was a challenging subject and they really enjoyed. 9 of them (45\%) said that they took Paragraph Writing course to be more literate in writing. 
6 out of them (30\%) believed that learning EFL Paragraph Writing was important to get good job. This showed that the high rate of students' interest in taking Paragraph Writing course was to be more literate in writing $(45 \%)$.

2) Dealing with learning targets in terms of wants, it was clear that majority of the respondents (50\%) stated that the skills to develop through the paragraph writing course was the understanding the paragraph development, as illustrated in Figure 2.

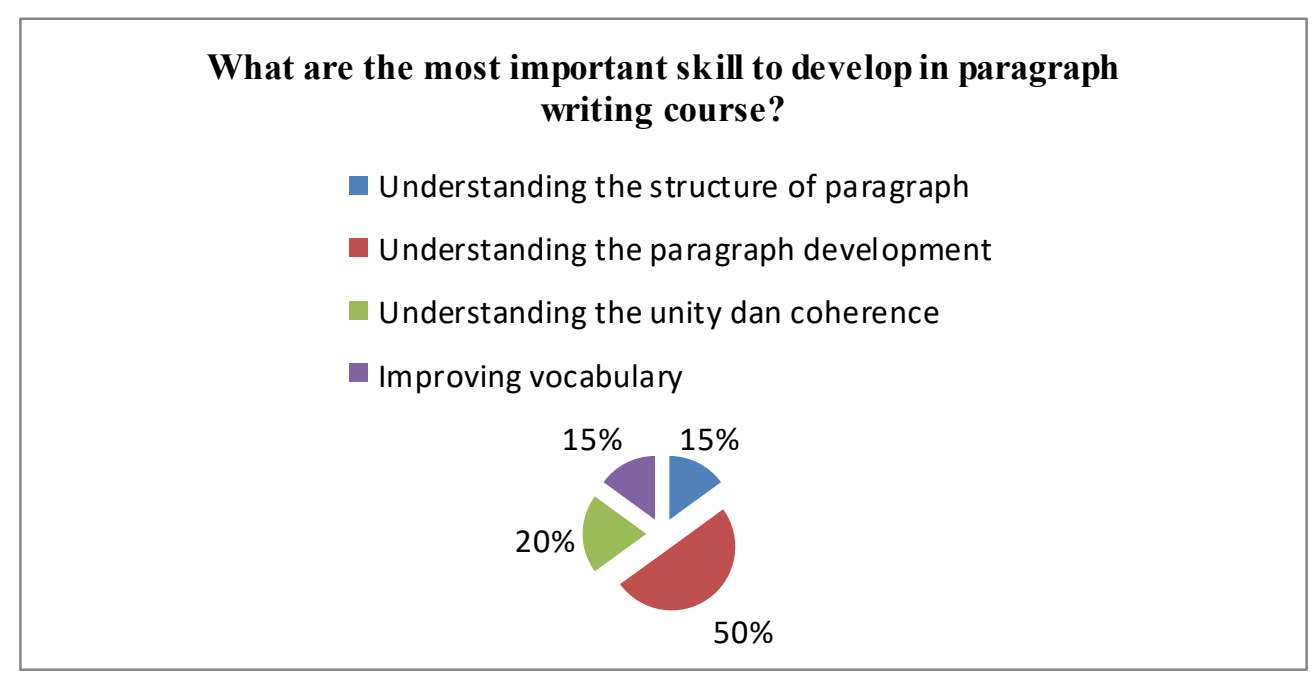

Figure 2. The target English language needs, in terms of their wants

Based on the data about the target English language needs, in terms of their wants, it was clear that majority of the respondents $(50 \%)$ stated that the most important skill to develop in paragraph writing course was the understanding the paragraph development.

3) Dealing with learning targets in terms of lack, it was clear that majority of respondents said that grammar $(45 \%)$ and mind mapping (40\%) was the students' difficulty in writing paragraph, as illustrated in Figure 3.

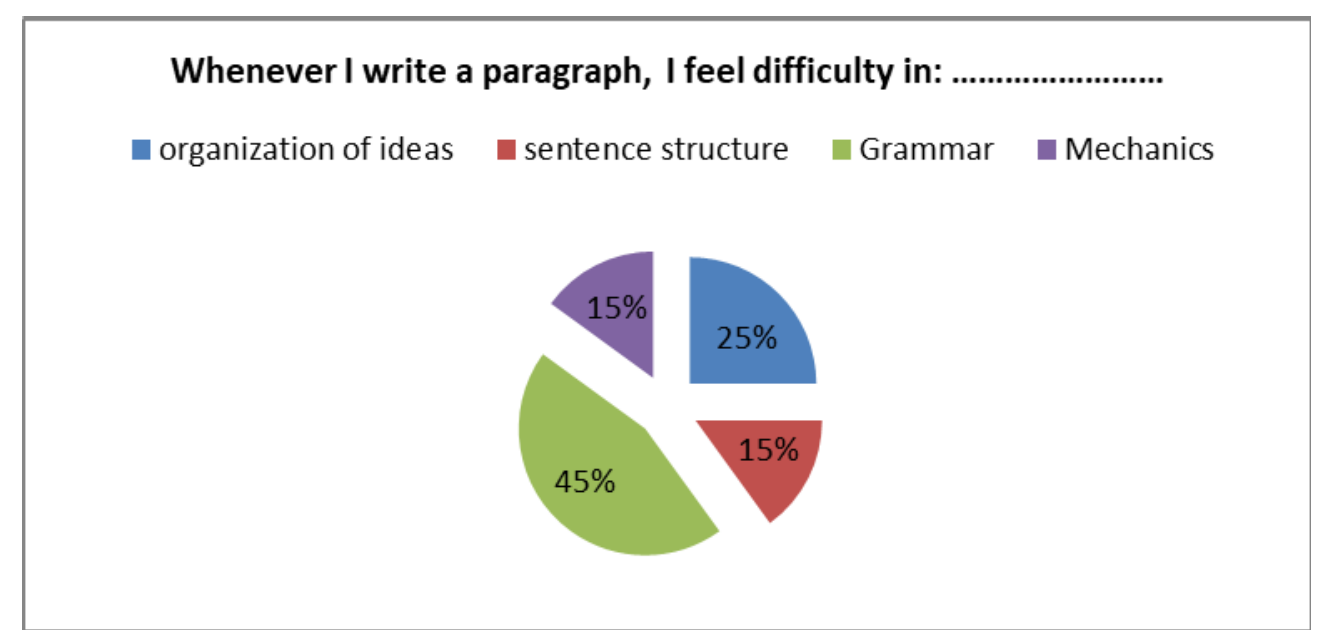

Figure 3. The students' difficulty in writing paragraph

The preference related to the students' difficulties in writing paragraph as shown in Figure 3. above indicated that grammar was the most difficulty among others, followed by organization of ideas, sentence structure and mechanics. It might because students often made grammatical errors when they were writing paragraph. Based 
on the data about the target English language needs, in terms of their lacks, it was clear that majority of respondents said that grammar (45\%) and mind mapping (40\%) were the students' difficulty in writing paragraph.

4) Dealing with learning needs in terms of learning style, the findings revealed that the learners preferred to get assistance from Internet than other sources, and they preferred to self-learn in the classroom activities. In terms of the learners' appropriate teaching methods in L2 writing class, it was found that (a) most learners (50\%) preferred to guided composition as their favorite classroom activities; (b) news was preferred dominantly by the respondents (35\%) as the most interesting model text to stimulate writing; (c) Internet was preferred dominantly by the respondents (75\%) as source to be included as instructional materials for Paragraph Writing course; (d) 100 minute was preferred mostly by the respondents $(85 \%)$ as the appropriate allocated time per week for Paragraph Writing course; (e) take home assignment was preferred mostly by the respondents $(30 \%)$ as the appropriate model of assessment in assessing students' writing ability; (f) the source of corrective feedback preferred mostly by the respondents $(80 \%)$ was teacher feedback; and $(\mathrm{g})$ the coverage topics preferred mostly by the respondents $(50 \%)$ was the structure of paragraph, as illustrated in Figure 4.

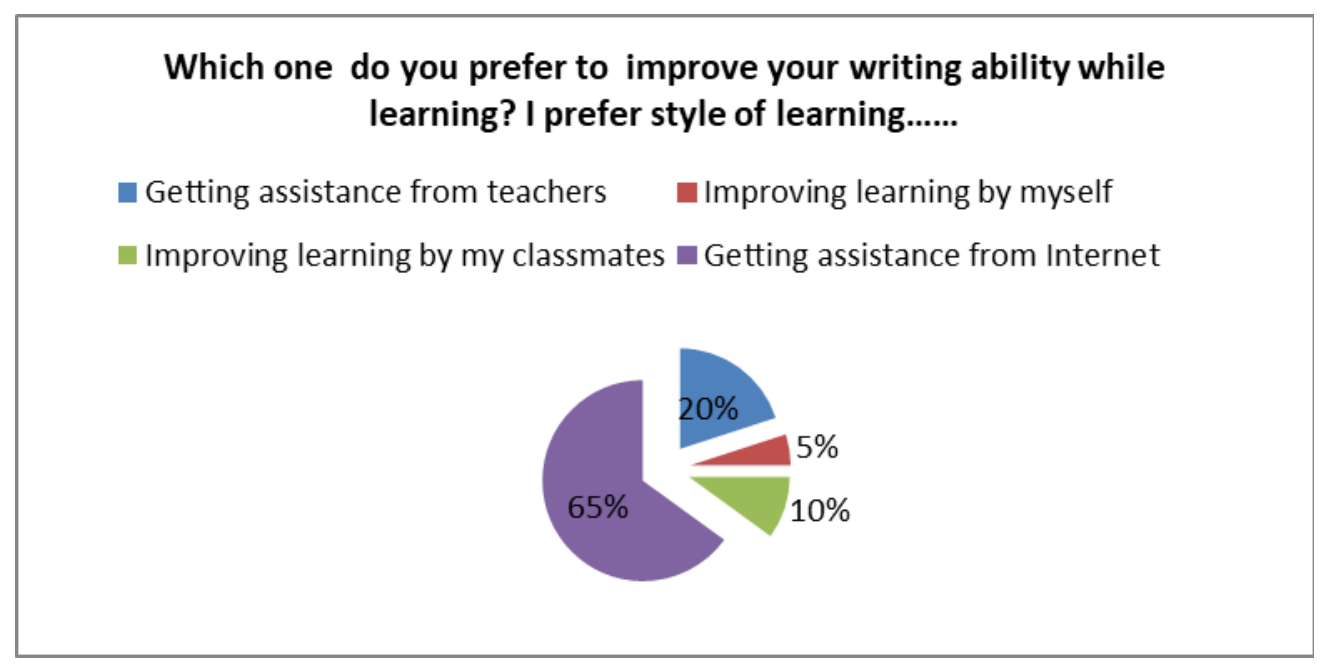

Figure 4. The students' preference style in the classroom activities

Based on the figure above about the learning needs of the students in L2 writing class, it was clear that majority of respondents said that getting assistance from internet $(65 \%)$ and self-learning $(65 \%)$ were the students' highest choices in their preference of learning style.

Dealing with the question: What are your favorite activities to improve your writing skills after class activities? The result showed that 6 respondents or 30\% preferred to watching English movies; 2 respondents or 10\% preferred to writing English daily journal; 3 respondents or 15\% preferred to attending English writing club; and 9 out of them or $35 \%$ preferred to browsing Internet 1 as their favorite activities to improve their writing skills after class activities, as illustrated in Figure 5 . 


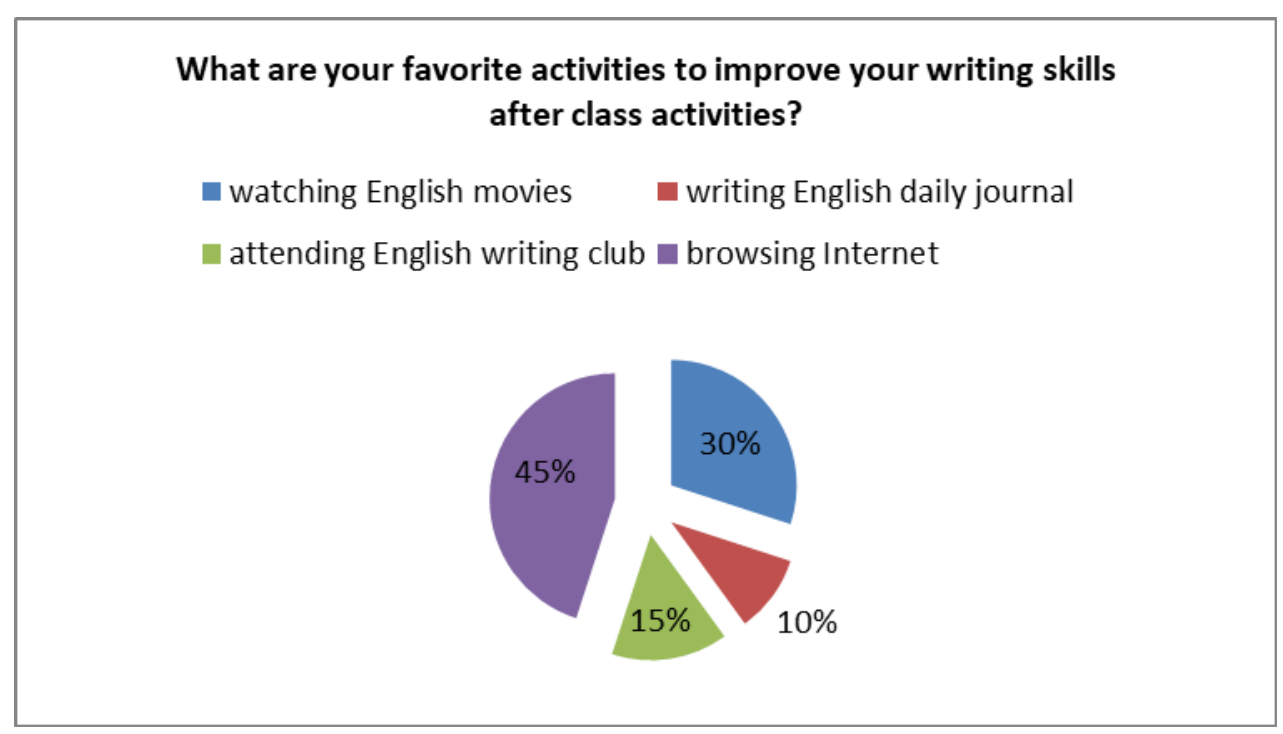

Figure 5. The learners' favorite activities to improve their writing skills after class activities

Dealing with the question: What sources are to be included as instructional materials for Paragraph Writing course? The result showed that 1 respondent or $5 \%$ preferred to handouts; 15 respondents or $5 \%$ preferred to Internet; 2 respondents or $10 \%$ preferred to newspapers/ magazines; and 2 respondents or $10 \%$ preferred to Podcast as sources to be included as instructional materials for Paragraph Writing course, as illustrated in Figure 6.

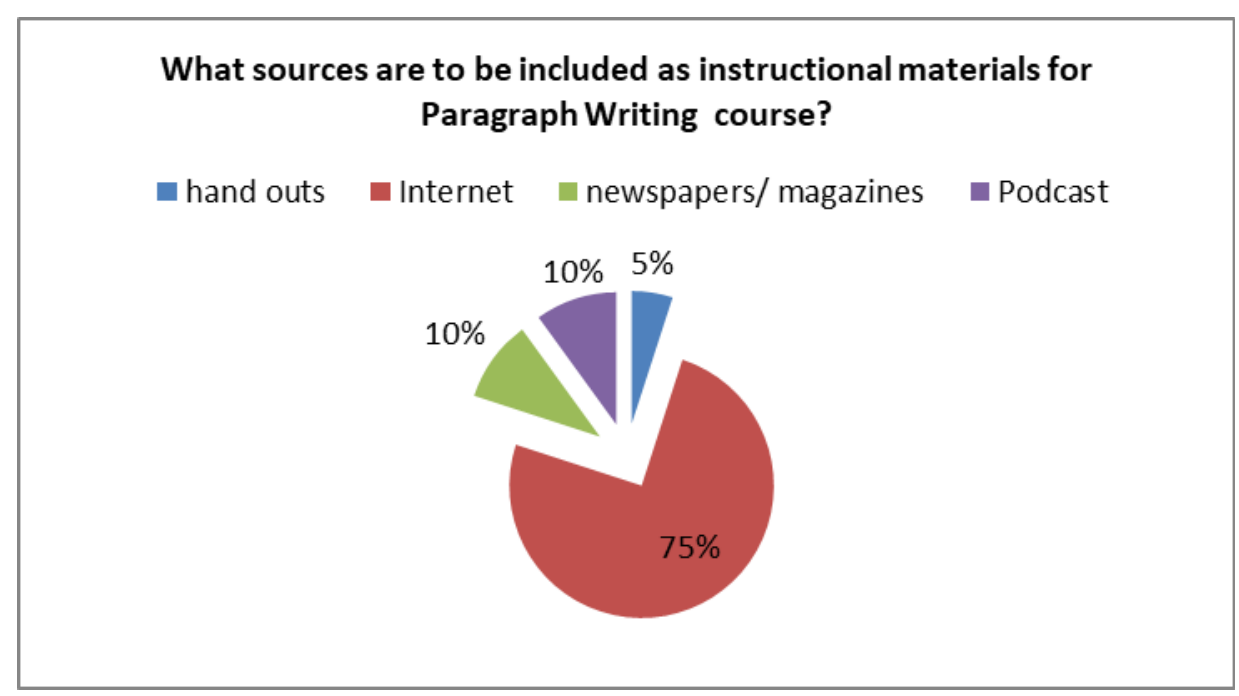

Figure 6. The learners' opinion on sources to be included as instructional materials for paragraph writing course

Based on the data above, it could be stated that the learners' appropriate teaching methods in L2 writing class were as follows; Internet was preferred dominantly by the respondents $(75 \%)$ as source to be included as instructional materials for Paragraph Writing.

\section{Discussion}

\subsection{Learning Targets in Terms of Necessity}

From the output, it was clear that some learners (45\%) were studying Paragraph Writing course because they wanted to be more literate in writing. 30\% of learners believed that learning EFL Paragraph Writing was important to get good job. The information about students' goal in L2 writing contributed to conceptualizing contents and objectives of material in the curriculum proposal. The findings revealed that the reason for the 
learners to study Paragraph Writing course was that they wanted to be more literate in writing and they believed that learning EFL Paragraph Writing was important to get good job. This made sense that they would be more literate in writing in order to get good job. They could communicate in international language.

\subsection{Learning Targets in Terms of Wants}

From the output, it was stated that half the respondents $(50 \%)$ stated that the skills to develop through the paragraph writing course was the understanding the paragraph development. This result also contributed to this study to identify the writing skills to be improved in EFL writing materials. The findings revealed that mastering paragraph development was an important skill to develop writing paragraph. The information about students' interest in L2 writing contributed to conceptualizing contents of material. Results showed that some students considered that understanding the paragraph development was the important skill to develop.

\subsection{Learning Targets in Terms of Lack}

From the data, it was clear that majority of respondents said that grammar $(45 \%)$ and mind mapping $(40 \%)$ was the students' difficulty in writing paragraph. The information about students' difficulties in L2 writing contributed to mapping material contents and teaching strategy. The finding showed that majority of the students considered grammar and mind mapping were the students' difficulty in writing paragraph. Teaching strategies or methodologies gave significant contribution to the curriculum. This was in line with Richards and Rodgers (2001) stating that methodologies and approaches had significant contribution the classroom activity; teachers' duty and class activity should be aimed at achieving the activation of various learning styles. In this sense, teachers had to provide adequate tools for students to be part of metacognitive learning processes and use it as benefits to explore EFL Skills.

\subsection{Learning Needs of the Learners}

Learning needs were the needs that ought to be fulfilled to help students learn (Hutchinson \& Waters, 1987). In order to help students learn writing, it was crucial to find out the students' learning needs. In terms of learning style, the findings revealed that the learners preferred to get assistance from Internet than other sources, and they preferred to self-learn in the classroom activities. Another aspect to be considered in developing EFL writing curriculum was the exploration of learners' learning styles. This data produced guidance about the way students learn and the way to teach them. In this case, learning experiences should provide the activities dealing with learning styles contributed to learners' learning. The finding of the learning styles recommended that majority of the learners learnt better using internet-based materials. Finally, internet-based materials were the most important thing of the designing curriculum proposal.

From the output, it could be concluded that the learners' appropriate teaching methods in L2 writing class were as follows (a) most learners (50\%) preferred to guided composition as their favorite classroom activities; (b) news was preferred dominantly by the respondents $(35 \%)$ as the most interesting model text to stimulate writing; (c) Internet was preferred dominantly by the respondents (75\%) as source to be included as instructional materials for Paragraph Writing course; (d) 100 minute was preferred mostly by the respondents (85\%) as the appropriate allocated time per week for Paragraph Writing course; (e) take home assignment was preferred mostly by the respondents (30\%) as the appropriate model of assessment in assessing students' writing ability; (f) the source of corrective feedback preferred mostly by the respondents (80\%) was teacher feedback; and (g) the coverage topics preferred mostly by the respondents $(50 \%)$ was the structure of paragraph.

Knowing the learners needs was vital and important in making decisions on the teaching procedures and learning materials to use (Davies, 2006) in order to reach the appropriate learning outcomes and support learners to become active class members in the EFL writing class. Effective EFL writing class could only be realized when teachers were aware of the learners' needs, wants and lacks.

The data obtained through this study gave significant contribution to develop appropriate activities, materials and contents in the process of EFL writing. In this case, Wentzel and Wigfield (2009) affirmed that the joyful learning could increase learners' interest and motivation. In this case, one of the aims of this EFL writing curriculum proposal was to catch students' interest so that EFL writing class is an interesting, enjoyable and useful.

Therefore, gathering information about learning targets in terms of necessity, wants, and lack of the learners was aimed at developing and choosing appropriate materials and objectives to make a design of EFL writing materials that met learners' needs. Another important aspect that should be considered was internet resources. Internet resources were important things in developing the current EFL writing curriculum. Based on the findings, in terms of resources, it was proved that learners enjoyed learning activities when they used internet as 
one of learning resources.

Finally, the findings suggested, first, internet-based materials was preferred when developing EFL writing materials. Second, teacher should make excellent integration of resources available on the web. Third, teacher should pay attention to the students' grammatical errors since they were still weak in grammar.

The result of the study was in accordance with Sumarsono, Bagis, and Arrafii (2017). Their findings showed that the learners' ability level was at the elementary level. Furthermore, the learners' needs in learning EFL writing included picture-enriched materials, EFL academic writing, and theories-driven writing materials. The findings were used as a basis of knowledge to develop EFL writing materials.

\section{Conclusions and Suggestions}

\subsection{Conclusions}

The study attempts to investigate the target needs and the learning needs of the students in Paragraph Writing class, in terms of (a) necessities; (b) wants; and (c) lacks; and the learning needs of the students, in terms of (a) preferred style of learning chosen by learners; (b) the suitable teaching procedures. The findings concluded:

1) Dealing with learning targets in terms of necessity, it was clear that some learners $(45 \%)$ were studying Paragraph Writing course because they wanted to be more literate in writing. $30 \%$ of learners believed that learning EFL Paragraph Writing was important to get good job.

2) Dealing with learning targets in terms of wants, it was clear that majority of the respondents (50\%) stated that the skills to develop through the paragraph writing course was the understanding the paragraph development.

3) Dealing with learning targets in terms of lack, it was clear that majority of respondents said that grammar $(45 \%)$ and mind mapping $(40 \%)$ was the students' difficulty in writing paragraph.

4) Dealing with learning needs in terms of learning style, the findings revealed that the learners preferred to get assistance from Internet than other sources, and they preferred to self-learn in the classroom activities. In terms of the learners' appropriate teaching methods, it was found that (a) most learners $(50 \%)$ preferred to guided composition; (b) news was preferred dominantly by the respondents (35\%); (c) Internet was preferred dominantly by the respondents (75\%) as source to be included as instructional materials for Paragraph Writing course; (d) 100 minute was preferred mostly by the respondents $(85 \%)$; (e) take home assignment was preferred mostly by the respondents (30\%); (f) the source of corrective feedback preferred mostly by the respondents $(80 \%)$ was teacher feedback; and $(\mathrm{g})$ the coverage topics preferred mostly by the respondents $(50 \%)$ was the structure of paragraph.

\subsection{Suggestions}

Below are the suggestions based on the research findings, addressed to education practitioners, syllabus and curriculum developers and future researchers.

1) As majority of students joining paragraph writing class want to be more literate in writing and want to get good jobs, so the designed curriculum should be matched in accordance with the learners' needs.

2) It is evidenced from the output that learners find lack of grammar and mind mapping strategy in writing paragraph. To help learners overcome this problem, it is suggested that activities like practicing writing, introducing various model of graphic organizers be given more space for EFL learners.

3) It is recommended that internet-based materials and activities are preferred when developing EFL paragraph writing materials. The materials should be made excellent integration of resources available on the web. The revised EFL writing materials should be learner centered and take learners' varied learning styles.

4) It is recommended that the next researchers follow up these findings using different views namely learners' level, learners' preference on learning style and teaching method, and so on. It is important because there are still a number of problems in developing EFL writing appropriate with the learners' needs.

\section{Acknowledgments}

The researcher would like to acknowledge indebtedness, appreciation and gratitude to the rector of IAIN Palangka Raya, Dr. Ibnu Elmi A.S. Pelu, SH, MH., the head of P2M, Drs. Ajahari, M. Ag., Dr. Desi Erawati, M. Ag. the chair woman of Research and Publication for the professional encouragement and financial support to realize the research. The appreciation and gratitude are also addressed to the EFL learners of English Department as the respondents of the study for readily answering the questionnaires; the authors of the books and persons responsible for the different websites visited and used by the researcher for the knowledge and wisdom; his colleagues for the professional inspiration; his families for the moral support; and above all, the blessing of God for completing this research report. 


\section{References}

Bosher, S., \& Smalkoski, K. (2002). From needs analysis to curriculum development: Designing a course in health-care communication for immigrant students in the USA. English for Specific Purposes, 21(1), 59-79. https://doi.org/10.1016/S0889-4906(01)00002-3

Brown, H. D. (2001). Teaching by Principles: An Interactive Approach to Language Pedagogy (4th ed.). White Plains, N Y: Addison Wesley Longman, Inc.

Chaudron, C. (2005). A task based needs analysis of a tertiary Korean as a foreign language program. In M. Long. (Ed.), Second language needs analysis (pp. 225-261). Cambridge: Cambridge University. https://doi.org/10. 1017/CBO9780511667299.009

Davies, A. (2006). What do learners really want from their EFL course? ELT Journal, 60, 3-12. https://doi.org/ $10.1093 / \mathrm{elt} / \mathrm{cci076}$

Finney, D. (2002). The ELT curriculum: A flexible model for a changing world. In J. C. Richards, \& W. A. Renandya (Eds.), Methodology In Language Teaching: An Anthology Of Current Practice (pp. 69-79). Cambridge: Cambridge University Press. https://doi.org/10.1017/CBO9780511667190.012

Hamp-Lyons, L. (2001). English for Academic Purposes. In R. Carter, \& D. Nunan (Eds.), The Cambridge Guide to Teaching English to Speakers of Other Languages. (pp. 126-130). Cambridge: Cambridge University Press. https://doi.org/10.1017/CBO9780511667206.019

Hutchinson, T., \& Waters, A. (1987). English for Specific Purpose. Cambridge: Cambridge University Press. https://doi.org/10.1017/CBO9780511733031

Iwai, T., Kondo, K., Limm, S. J. D., Ray, E. G., Shimizu, H., \& Brown, J. D. (1999). Japanese language needs analysis. Retrieved May 2018 from http://www.nflrc.hawaii.edu/Networks/NW13/NW13.pdf

Kaewpet, C. (2009). A framework for investigating learner needs: Needs analysis extended to curriculum development. Electronic Journal of Foreign Language Teaching, 6(2), 209-220.

Kathryn, R., \& Wentzel, A. W. (2009). Handbook of motivation at the school.

Maria D. T. (2014). Designing and administering a needs analysis survey to primary school learners about EFL learning: A case study. Preschool \& Primary Education, 2(1), 59-82.

Richards, J. C. (1990). The language teaching matrix. Cambridge: Cambridge University Press. https://doi.org/10.1017/CBO9780511667152

Richard, J. C., \& Renandya, W. A. (2002). Methodology in Language Teaching. An Anthology of Current Practice. Cambridge: Cambridge University Press. https://doi.org/10.1017/CBO9780511667190

Richards, J. C. (2002). Curriculum Development in Language Teaching. USA: Cambridge.

Richards, J., \& Rodgers, T. (2001). Approaches and methods in language teaching. England: Cambridge University Press. https://doi.org/10.1017/CBO9780511667305

Said, A.-S., \& Moses, S. (2015). The Writing Needs of Omani EFL Students For Tile Development of Grade 11 English Program: A Needs Analysis.

Songhori, M. H. (2007). Introduction to Need analysis. English For Specific Purposes World, 4.

Suad, A. Al-H., \& Abdallah, A. B. (2015). A Needs Analysis Approach to EFL Syllabus Development for Second Grade Students in Secondary Education in Saudi Arabia: A Descriptive Analytical Approach to Students' Needs American International Journal of Contemporary Research, 5(1).

Sumarsono, D., Bagis, A. K., \& Arrafii, M. A. (2017). Students' Needs to Develop English Writing Materials. Lingua Cultura, 11(2), 67-71. https://doi.org/10.21512/lc.v11i2.1504

Yalden, J. (2012). Principles of course design for language teaching. Cambridge: Cambridge University Press.

\section{Copyrights}

Copyright for this article is retained by the author(s), with first publication rights granted to the journal.

This is an open-access article distributed under the terms and conditions of the Creative Commons Attribution license (http://creativecommons.org/licenses/by/4.0/). 